Please quote as: Peters, C.; Kromat, T. \& Leimeister, J. M. (2015): Complex Services and According Business Models - Design and Evaluation of an Analysis Framework in the Field of Telemedicine. In: 48th Hawaiin International Conference on System Sciences (HICSS), Koloa, Hawaii, USA. 


\section{Complex Services and According Business Models - Design and Evaluation of an Analysis Framework in the Field of Telemedicine}

\author{
Christoph Peters \\ Information Systems, \\ Kassel University \\ christoph.peters@uni-kassel.de
}

\author{
Theresa Kromat \\ Information Systems, \\ Kassel University \\ theresa.kromat@,wi-kassel.de
}

\author{
Jan Marco Leimeister \\ Information Systems, \\ Kassel University \\ leimeister@uni-kassel.de \\ Institute of Information \\ Management, \\ University of St. Gallen \\ JanMarco.Leimeister@unisg.ch
}

\begin{abstract}
Successful business models in the field of complex services are rare and often not profitable so far. In this design science research paper, we build and evaluate an analysis framework for such business models using the exemplary field of telemedicine. The framework is a morphological box. Its dimensions are derived from existing literature. In a second iteration and after applying it to 16 services, it is refined. The resulting artifact reveals three types of typical business model: enablers, supporters and patient-centered innovators. Besides the identification of these types, the framework allows service providers for the delimitation of own business models to others, for assessing competitors and consequently for the informed design of features leading to competitive advantages. The framework's structure allows for the elicitation of white spots - so far not existing patterns - for future business models and facilitates the provider's strategic positioning within the market and potential future adaptations.
\end{abstract}

\section{Introduction and Motivation}

Service has grown into an important field for research in information systems [1], as information technology (IT) is currently revolutionizing the way services are delivered. Many services hereby not only play a key role for societal advancements, but become necessary [2]. On the one hand, IT enables new forms of cooperation and communication in service [1]; on the other hand, it enables automation, standardization and new concepts for customer integration [3].

This is especially true for complex services, but also makes it complicated and is not reflected in many current business models. We used the field of telemedicine for the scope of this design science research project presented here, because it represents a typical example for complex services and it is a promising field that due to many technological advancements in the last years is highly promising, but poorly applied in everyday health care provision. Nevertheless, health care systems need telemedical services (TMS) in order to support physicians, nurses etc. in delivering medical services in a patient-centered way that respects the heterogeneous needs of their stakeholders lacks acceptance.

By now, most TMS are often tested as pilot projects only. That is why the comprehensive study of their underlying business models calls for action.

So, analyzing currently applied business models in the field of telemedicine would be a formidable starting point. The analysis framework we present here aims for providing insights into three substantial features of business models: 1) the thorough description of the service offering, its value-creation, etc. in order to explain the business model better; 2) the analysis of the constituting parts and perspectives of the business model itself; 3) the post-analysis strategic planning for redeveloping existing or even creating new business models. By its nature and because business models always seek the means of establishing competitive advantages, all of the above is not only restricted to the own business model of a specific TMS provider, but instead the consideration of these dimensions for competing providers is supposed to provide insights in a systematic manner.

By conducting a literature review, we detected that the field of telemedicine lacks of appropriate business models. We seem to have faced a solved problem because there are business models in the field of telemedicine already. Following [4], our work aims at addressing a solved problem in a more efficient and effective way. 
That is why we present the design and evaluation of an analysis framework for such business models, give insights and results.

The paper at hand is structured as follows: In chapter 2, we provide the background for our research setting and outline the following topics: complex services, the field of telemedicine, and business models. Chapter 3 presents the methodology we used to build and evaluate our analysis framework. As for results, the three derived business model types and according real-world examples are presented in chapter 4 and discussed in chapter 5. Chapter 6 clarifies our theoretical and practical contribution. The paper closes with limitations and potential future research activities in chapter 7 and 8.

\section{Background}

\subsection{Complex Services}

A service itself is "(a set of) activities being part of interactions between the components of service systems" [5]. It is a complex phenomenon. Within the scope of this paper, complex services consist of a combination of both, IT and non-IT services, while the latter also integrate highly knowledge-intense, personoriented [6] and interactive parts as well.

Within the service sector, more and more complex services come into existence. As an example for such complex services, the field of telemedicine can be taken and is used for illustration purposes in the remainder of this paper. Complex services are further characterized by a large number of stakeholders [7], e.g., in the field of telemedicine by physicians, care personnel, service providers, technology manufacturers or telecommunication companies. Telemedicine hereby is the provision of medical services over geographic distances through the use of information and communication technology [8].

Additionally, complex services are defined by a high degree of heterogeneity because of their personoriented fashion.

\subsection{The Field of Telemedicine}

TMS comprise a very heterogeneous market, ranging from telemonitoring services (e.g., defibrillators that capture and transfer the patients' heart beat data in order to enable physicians to monitor the patients' heart functions remotely and to trigger alarm functions automatically) to teleconsultation services that enable experts to guide other physicians through the conduction of medical procedures, e.g., in telestroke units [9]. TMS are therefore beneficial in supporting a patient's quality of life [10] and, where implemented, can reduce the cost of delivering health care. Despite being considered medically and technically viable, few TMS innovations have been put into practice $[11,12]$. The reasons TMS are not seeing a widespread implementation include - besides a lack of suitable business models - difficulties in integrating them into existing health care treatment processes, and usability and acceptance issues on the part of physicians and patients. The market for telemedicine is continuously growing, from $\$ 9.8$ billion in 2010 to $\$ 23$ billion in 2015 [13] worldwide and reaching $\$ 5$ billion in 2015 within the European market [14]. For service providers who want not only to benefit from this expected growth but also to leverage their own market potentials in a competitive market, this prospect calls for flexibility and solidly grounded business models in this fast-changing market.

\subsection{Business Models}

A business model presents the company's core business activities [15]. An appropriate business model is crucial for a company's economic success [15].

While complex services are provisioned in service systems, i.e., work systems generating a service [16], comprising a plethora of stakeholders, activities, etc., the providers are in focus of business model considerations. Business model research can be crucial, especially in service science [17].

For complex services at the edge of digitization and person-orientation, business models are not studied in detail so far. Still, business model research on services with IS focus root back later than a decade [18-20].

Business models can serve as instruments for strategic planning by supporting managers in "planning new business activities and developing business activities", which are already in existence, as outlined by [21]; [22].

Two of the most comprehensive and well-known in literature might be the ones by Osterwalder and Pigneur [23, 24] and Wirtz [25].

While Osterwalder's business model canvas comprises the nine building blocks customer segments, value proposition, channels, customer relationship, revenue streams, key resources, key activities, key partnerships, and cost structure; Wirtz approach is constituted by the following parts: market model, service offering model, goods and services model, procurement-/ distribution model, organization-/ cooperation model, and capital model.

As these are only two examples and business models have been and are being widely discussed in literature so far, business models and business model frameworks intended many different aims and in 
regards to our three goals presented above (description, analysis and strategic planning / new creation of business models), we have studied existing literature and could gain the following overview presented in Table 1.

\begin{tabular}{|c|c|c|}
\hline \multicolumn{3}{|c|}{$\begin{array}{c}\text { Table 1. An Overview of Business Model Elements } \\
\text { and Purposes by different Authors (source: own } \\
\text { illustration) }\end{array}$} \\
\hline Authors & $\begin{array}{ll}\text { Business model } \\
\text { elements }\end{array}$ & $\begin{array}{l}\text { Business } \\
\text { model purpose }\end{array}$ \\
\hline $\begin{array}{l}\text { Ansorge et al. } \\
{[26]}\end{array}$ & $\begin{array}{ll}\text { BMC } & \text { by } \\
\text { Osterwalder } & \\
\end{array}$ & Description \\
\hline $\begin{array}{l}\text { Gersch/ } \\
\text { Hewing [27] }\end{array}$ & $\begin{array}{lr}\text { Business } & \text { model } \\
\text { framework } & \text { by } \\
\text { Wirtz } & \end{array}$ & $\begin{array}{l}\text { Description and } \\
\text { analysis }\end{array}$ \\
\hline $\begin{array}{l}\text { Schultz et al. } \\
{[28]}\end{array}$ & $\begin{array}{l}\text { Value model; } \\
\text { Internal and } \\
\text { external value } \\
\text { creation model }\end{array}$ & $\begin{array}{l}\text { Analysis and } \\
\text { communication }\end{array}$ \\
\hline $\begin{array}{l}\text { Gemünden/ } \\
\text { Hensel/ } \\
\text { Schultz [29] }\end{array}$ & $\begin{array}{l}\text { Value model; } \\
\text { Internal and } \\
\text { external value } \\
\text { creation model }\end{array}$ & $\begin{array}{l}\text { Analysis and } \\
\text { communication }\end{array}$ \\
\hline Osl et al. [30] & $\begin{array}{l}\text { Customer and } \\
\text { service offering; } \\
\text { Value creation; } \\
\text { Paying entity \& } \\
\text { revenues } \\
\text { marketing model }\end{array}$ & Description \\
\hline $\begin{array}{l}\text { Valeri et al. } \\
{[31]}\end{array}$ & $\begin{array}{ll}\text { BMC } & \text { by } \\
\text { Osterwalder } & \\
\end{array}$ & $\begin{array}{l}\text { Analysis and } \\
\text { communication }\end{array}$ \\
\hline
\end{tabular}

As one can see, purpose and intended use varies widely and also the well-known concepts of Osterwalder and Wirtz only partly manage to include all three aims or are capable of coping with complex services and TMS particularities.

That is why we integrated theworks of different authors as well as our own ideas in order to address the specific needs of the TMS environment.

\section{Research Setting}

"[...] a problem can be defined as the differences between a goal state and the current state of a system." [4]; [32]. "[...] design-science research addresses important unsolved problems in unique or innovative ways or solved problems in more effective or efficient ways." [4]. That is the reason why, the design-science paradigm is defined as a problem-solving paradigm [4]. According to [15], the business problem is defined as follows: the currently applied business models in the field of telemedicine do not consider TMS-specific structures. In consequence, the TMS a TMS provider offers cannot be modeled in an appropriate way. Thus we define the business problem as a solved problem because the TMS providers are able to model their TMS by using currently applied business models. The identification of service patterns in the field of telemedicine could address the above mentioned business problem in a more efficient and effective way.

In order to address the solved problem, we conduct IS design science research by building and evaluating an artifact according to [4]. We develop an analysis framework, that includes value- and service-oriented aspects [15] and is based on the ideas of [22]; [33] and $[34,35]$. Bieger and Reinhold's work [36] is used on the one hand, but on the other hand, we also considered [33] and integrated Vargo and Lusch's perspective of service-dominant logic [35]. All in all, the integration of these different aspects is supposed to strengthen our analysis framework.

The analysis framework's purpose is to identify business model types by testing currently applied business models in the field of telemedicine.

Our analysis framework comprises of four dimensions: (a) value proposition, (b) value cocreation, (c) value communication and transfer, and (d) value capture. By using these dimensions, we meet the following requirements: defining products, defining customer segments, defining organizational arrangements, and calculating costs and revenue flows [15]; [37]. Our analysis framework focuses on TMS by taking in account their specific structures [15]. The analysis framework is going to be discussed in more detail in the next chapters.

We perform two rigor cycles [38], and after the first iteration of the analysis framework which is purely built on an extensive study of the existing body of knowledge, it is refined and extended using the insights from practice in the second iteration.

The analysis framework has the form of a morphological box, i.e., it consists of a number of dimensions. Each dimension comprises a given set of attributes. For each individual business model, one attribute can be attained per dimension. The described box is used for both iterations.

\section{Results}

\section{1 "Building" and "Evaluating" the Analysis Framework}

Based on the literature examined, we focused on the setup for dimensions that guides the framework's structure. It is structured as a morphological box that is 


\begin{tabular}{|c|c|c|c|c|c|c|}
\hline Dimension & $\begin{array}{l}\text { Characteristic } \\
\text { (attribute) }\end{array}$ & \multicolumn{5}{|c|}{ Charateristic value } \\
\hline \multirow{6}{*}{ 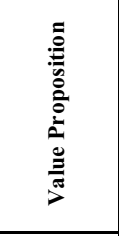 } & Domain "telemedicine" & Telemonitoring & Teleconsultation & Teleradiology & Teletheraphy & General \\
\hline & Medical purpose & Prevention & Diagnosis & Therapy & Provision & \\
\hline & Area of application & \multicolumn{2}{|c|}{ Determined } & \multicolumn{2}{|c|}{ Open } & \\
\hline & Customer & \multicolumn{2}{|c|}{ Health care provider } & \multicolumn{3}{|c|}{ Recipient (consumer) } \\
\hline & $\begin{array}{l}\begin{array}{l}\text { Benefit - (external) health care } \\
\text { provider }\end{array} \\
\end{array}$ & $\begin{array}{c}\text { Application of the telemedical } \\
\text { service }\end{array}$ & $\begin{array}{c}\text { Ideas for further development of } \\
\text { the telemedical service }\end{array}$ & No additional benefits & & \\
\hline & Benefit - recipient & \multicolumn{2}{|c|}{ Benefit is provided by applying the telemedical service } & \multicolumn{3}{|c|}{ No direct benefits } \\
\hline \multirow{5}{*}{ 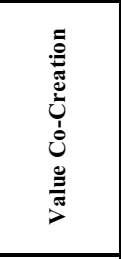 } & Supply & $\begin{array}{c}\text { Part of the telemedical service } \\
\text { offerings }\end{array}$ & Complementary supply/offer & Supply/offer & & \\
\hline & Contact - patient & Direct & Indirect & No contact & & \\
\hline & Service comprises & SW & HW & $\mathrm{HW}+\mathrm{SW}$ & No specific technology & \\
\hline & Medical know-how & Is not necessary & $\begin{array}{l}\text { Is necessary; is provided by } \\
\text { own staff }\end{array}$ & $\begin{array}{l}\text { Necessary; requires a co- } \\
\text { operation with a health care } \\
\text { provider }\end{array}$ & & \\
\hline & Reactivity & Direct reaction & Fowarding & Messaging & Delay & Non-critical \\
\hline 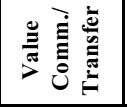 & Type of communication & Via IuK & Face-to-face & Combined & & \\
\hline \multirow{2}{*}{ 总泀 } & Type of revenue & Direct, depending on transaction & $\begin{array}{l}\text { Direct, irrespective of } \\
\text { transaction }\end{array}$ & $\begin{array}{l}\text { Indirect, depending on } \\
\text { transaction }\end{array}$ & $\begin{array}{l}\text { Indirect, irrespective of } \\
\text { transaction }\end{array}$ & \\
\hline & Assumption of costs & Third-party payer & Recipient (consumer) & Health care provider (?) & & \\
\hline
\end{tabular}

Figure 1. Exemplified TMS - results of the second iteration (source: own illustration)

used to identify patterns of the offering. Figure 1 and 6 show our morphological box by using a "reallife" TMS as an example. Figure 6 (in the appendix) presents the sample TMS in its first iteration, whereas figure 1 depicts the second (final) iteration.

In a first iteration, we build and evaluate the first analysis framework. It is tested within a "real-life" environment by using "real-life" TMS in order to prove the first analysis framework's applicability in such a context. We also want to find out which characteristics and characteristic values we have to revise in order to develop our tool further. These "reallife" TMS originate from the "ehealth@home map" as well as from an extensive internet search. The requirement, which the TMS have to fulfill for inclusion, is to provide enough information for completing the analysis framework. All in all, we gathered data of $16 \mathrm{TMS}$ that fit with the chosen characteristics and characteristic values [15].

The feedback that was provided by the first iteration is used to conduct another "build-andevaluate"-cycle [38]. The aim of this second iteration is the reduction of complexity and clear delimitation between dimensions of the framework. Considerations regarding the service-concept and creation of valueconcept are improved by adding practical knowledge [15].

Our analysis framework allows internal and external comparisons of different TMS. By comparing different TMS, we found out that business models in the field of telemedicine are based on three different service patterns [15]. In the next chapter, we are going to explain these service patterns in more detail.

\subsection{Three Business Model Types in the Field of Telemedicine}

As a result, we identified three types of business models in the field of telemedicine: (a) enabler, (b) supporter, and (c) patient-centered innovator. In the following sections, we are going to explain these business model types in more detail and illustrate them by using one "real-life" example each.

(a) "Enabler" business models enable the delivery of TMS by providing the applications. Health care providers such as hospitals and physicians are these TMS' customers; the patient as a customer and/ or consumer is irrelevant [15].

The following service reflects an "enabler" business model type: A company offers a telematics platform that integrates different TMS and connects different health care providers [15]. Figure 2 shows the "enabler" business model type. 

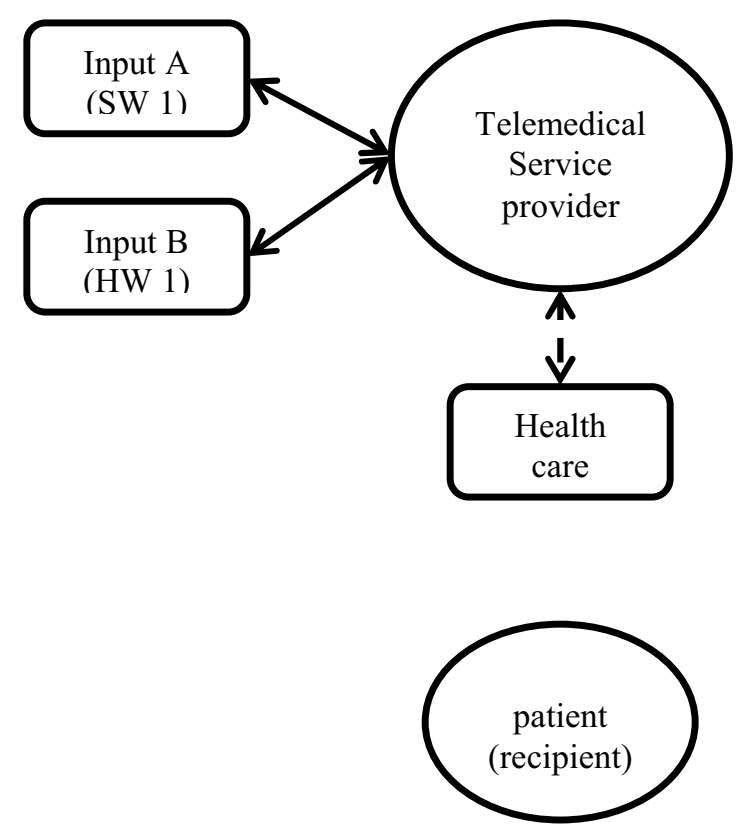

Figure 2. Type of business model "enabler" (source: own illustration)

(b) "Supporter" business models support medical service providers by offering TMS that are applicable to a certain medical field. Health care providers such as hospitals and physicians offer these TMS to the patients; the health care providers' medical know-how is needed [15].

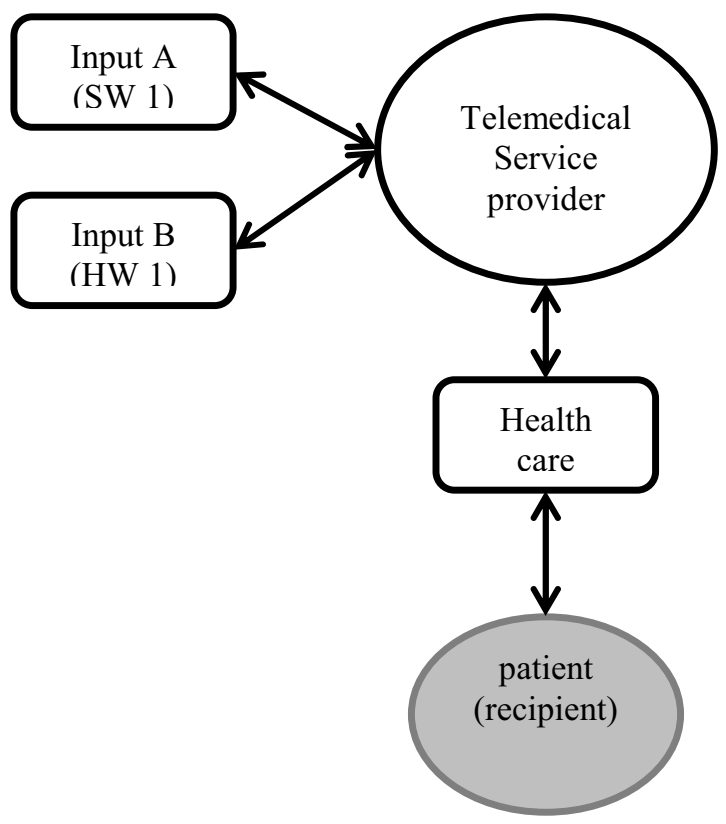

Figure 3. Type of business model "supporter" (source: own illustration)
The following TMS is based on a "supporter" business model type: This TMS helps patients, who suffer from diabetes, to document and save their blood glucose values. To safe a patient's blood glucose values in an online diary allows to model a patient's course of disease [15]. Based on such crucial information, a physician could get a better picture of a patient's disease. Figure 3 depicts the "supporter" business model type.

(c) "Innovator" business models are characterized by offering specific TMS to patients directly; health care providers as "intermediaries" are not needed [15].

The following TMS is based on an "innovator" business model type: The supplier provides the patients with a device that measures the patients' blood pressure. Data is documented automatically. If a patient forgets to measure her/ his blood pressure, $\mathrm{s} /$ he will be reminded [15]. The "innovator" business model type is presented in figure 4.

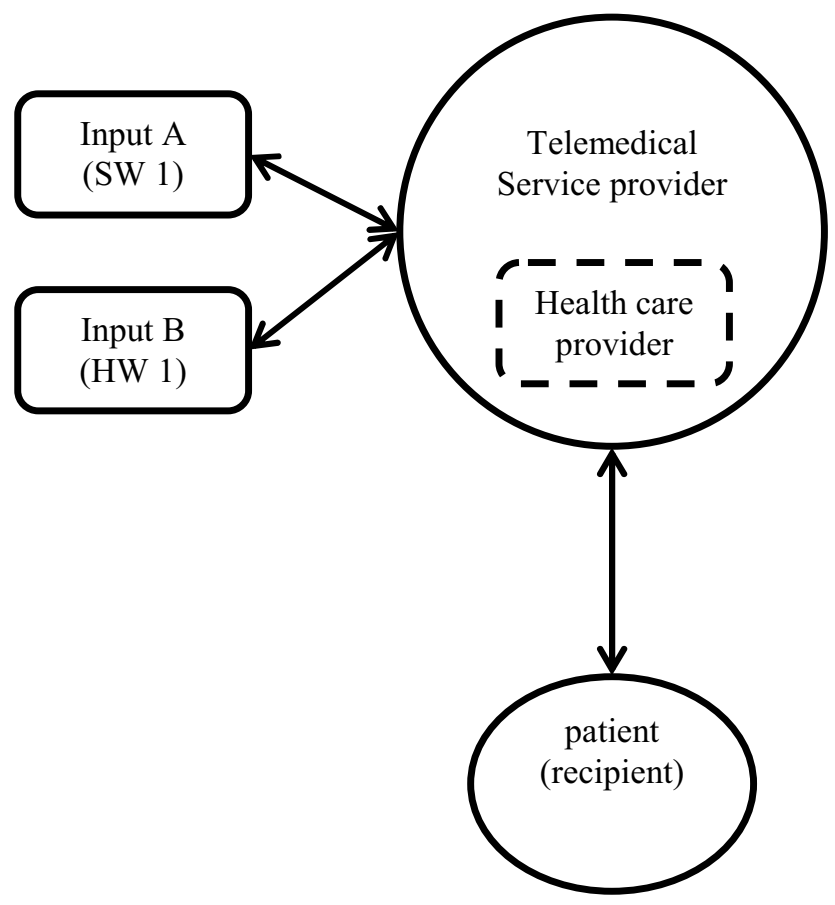

Figure 4. Type of business model "innovator" (source: own illustration)

\section{Discussion and Conclusion}

In this chapter, we discuss the advantages and disadvantages of the identified business model types as well as the challenges TMS providers have to face by applying these types of business models. Table 2 summarizes the discussion's main parts. 
An "enabler" business model can be exemplified by delivering a telematics platform. A telematics platform integrates different health care providers, e.g., hospitals and physicians working in doctor's offices, and gives them the opportunity to exchange data easily in order to perfect the provision of TMS by using the telematics platform; the latter one allows offering TMS to the patients. In our example, the health care providers are defined as customers because the initialization of the telematics platform is aimed at bringing together different health care providers; the patient is not involved in the consumption of the telematics platform.

In order to integrate different health care providers on a telematics platform successfully, an "enabler" business model must include its different customers and their different interests; to sum up, an "enabler" business model has to model the whole value network.

Such a model profits from a manageable number of stakeholders, i.e., the fewer agents are involved in the delivery of a (telemedical) service, the less complicated might it be.

In order to provide TMS, which are based on a "supporter" business model type, the TMS provider has to co-operate with external service providers. These external service providers are the health care providers (consisting of different agents) as well as the health insurance companies. On the one hand, such a co-operation allows the TMS provider to outsource different activities, e.g., reimbursement issues. On the other hand, the TMS provider is highly dependent on the external service providers' performance in delivering TMS. Moreover, the health insurance companies and their interests have to be added in the "supporter" business model's modeling as well.

By applying a patient-centered "innovator" business model type, a TMS provider can interact with its patients directly; an external service provider as an intermediary is not needed. First, the health insurance companies could be excluded because it is likely that the patients have to pay out-of-pocket. Second, there is no health care provider between the TMS provider and the patients because the TMS provider has the medical knowledge, which is needed to deliver the TMS to the patients, as shown in figure 4 . Nevertheless, the health care providers cannot be excluded because they are needed in terms of getting access to patients' data.

The "supporter" and "innovator" business model types have to define the role of the patients, too. The patients consume the TMS but other persons could be involved as well; think of parents, who pay for their child's medical treatment. They decide on the consumption of their child's / a patient's TMS. That is the reason why, they have to be considered as customers as well.
The discussion is followed by the three types of business models' contribution that is outlined in chapter 7.

\begin{tabular}{|c|c|c|}
\hline & Advantages & Disadvantages \\
\hline 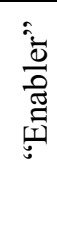 & $\begin{array}{l}+ \text { Revenues follow } \\
\text { because of service and } \\
\text { maintenance }\end{array}$ & $\begin{array}{l}\text { - In order to profit, a } \\
\text { customer (health care } \\
\text { provider) must develop } \\
\text { own ideas for } \\
\text { telemedical } \\
\text { applications }\end{array}$ \\
\hline 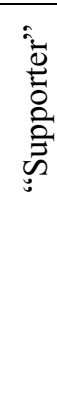 & $\begin{array}{l}+ \text { Medical know-how } \\
\text { is not necessary } \\
+ \text { Outsourcing specific } \\
\text { functions of the value } \\
\text { creation, e.g., } \\
\text { acquisition of } \\
\text { customers or patients, } \\
\text { and reimbursement } \\
\text { issues }\end{array}$ & $\begin{array}{l}\text { - Being highly } \\
\text { dependent on external } \\
\text { service providers; a } \\
\text { service } \\
\text { influences a service's } \\
\text { quality significantly }\end{array}$ \\
\hline 总 & $\begin{array}{l}+ \text { Keeping in touch } \\
\text { with recipients } \\
\text { directly; there is no } \\
\text { health care provider } \\
\text { between the TMS } \\
\text { provider and the } \\
\text { patient; service quality } \\
\text { is influenced by the } \\
\text { TMS provider } \\
\text { (supplier) itself } \\
+\quad \text { Probably the } \\
\text { patients have to pay } \\
\text { out-of-pocket }\end{array}$ & $\begin{array}{l}\text { - Developing a } \\
\text { clientele; a co-operation } \\
\text { with health care } \\
\text { providers is necessary } \\
\text { in order to get access to } \\
\text { a client's data (patient } \\
\text { data) }\end{array}$ \\
\hline
\end{tabular}

\section{Limitations \& Future Research}

In the scope of this paper, we focused on TMS as one field of complex services. Although it is a very well-chosen field and highly attractive and promising in terms of future developments, this represents a limitation in terms of our general insights for complex services. Of course, this automatically calls for future research in other fields of complex services, e.g., blended learning scenarios, etc. Most of the dimensions in our analysis framework will at least provide a very solid starting point to proceed here. 
It lies in the nature of our investigation that one limitation is the timeliness of our research, i.e., the fact that we could only include business models in our assessment that were known to us until the submission of this paper. Still, the field is highly active and new models are created or adapted day-by-day. We tried to cope with this challenge by relying on a source (the ehealth@home map which is continuously updated). Also, the scope of assessed business models are German-only and might inherit attributes reflecting the specifics of the German health care market.

Another interesting and planned approach would be the endeavor to combine existing work which considers [39] with the findings presented here.

It will be very interesting how our results and successful future business models need to be adapted in order to react on the recently announced plans of big digitization players such as Google or Apple who aim to increase their power within the IT-driven healthcare environment, respectively telemedicine field. Hereby, completely new structures of value creation and provision might be established that rely on so-called digital control points.

All topics and issues around open data and according consequences, challenges and chances [40] will influence future settings as well and call for indepth research activities. In particular, reflecting on the roles of involved entities [41, 42] seems highly relevant.

\section{Conclusion and Contribution}

Within this paper, we presented an analysis framework for the assessment of business models of complex services using the field of telemedicine. The framework is a morphological box which was designed and further developed during the process and includes both, theoretical basis and insights gained from practice. With the application of 16 services, three distinct types of business models could be elicited: enablers, supporters and patient-centered innovators. Besides the identification of these types, the framework allows service providers for the delimitation of own business models to others and for assessing competitors. By comparing these business models, TMS providers can assess the competitors' business models and can come up with ideas how to design and create own features which can lead to competitive advantages.

Consequently, it fosters the informed design of features leading to competitive advantages. If service providers want to extend or adapt their portfolio, they can identify "white spots" using so far unused patterns of the attributes of the framework's dimensions to get first ideas. Such white spots can be defined as superior knowledge, which can be used by TMS providers to address niches in the telemedical market.

Also, it is supposed to facilitate the provider's strategic positioning within the market and allows for well-informed adaptations of existing business models in the future.

A particularly interesting field for future research is if and how these new business models are affected by systematic approaches of modular service offerings [43] and especially in which way the models are influenced by open data modules.

In terms of theoretical contribution the presented framework extends the body of knowledge in regards to the "theory of design and action" [44].

\section{Acknowledgement}

The authors want to thank Mathias Kerkhoff for his valuable input.

\section{References}

[1] Rai, A., and Sambamurthy, V., "Editorial Notes - the Growth of Interest in Services Management: Opportunities for Information Systems Scholars", Information Systems Research, 17(4), 2006, pp. 327-331.

[2] Leimeister, J.M., and Peters, C., "Gesellschaftlich Notwendige Dienstleistungen - Soziale Innovationen Denken Lernen", in (Editor, 'ed.'^'eds.'): Book Gesellschaftlich

Notwendige Dienstleistungen - Soziale Innovationen Denken Lernen, Friedrich-Ebert-Stiftung, Abteilung Wirtschafts- und Sozialpolitik, Bonn, Germany, 2012

[3] Fitzsimmons, J.A., and Fitzsimmons, M.J., Service Management : Operations, Strategy, and Information Technology, McGraw-Hill/Irwin, 5th edn, Boston, 2005. [4] Hevner, A.R.M., Salvatore T.; Park, Jinsoo; Ram, Sudha, "Design Science in Information Systems Research", MIS Quarterly, 28(1), 2004, pp. 75-105.

[5] Leimeister, J.M., Dienstleistungsengineering Und Management, Springer Verlag, Berlin and Heidelberg, Germany, 2012.

[6] Menschner, P., Peters, C., and Leimeister, J.M., "Engineering Knowledge-Intense, Person-Oriented Services - a State of the Art Analysis", in (Editor, 'ed.'^'eds.'): Book

Engineering Knowledge-Intense, Person-Oriented Services a State of the Art Analysis, Helsinki, Finnland, 2011

[7] Janson, A., Peters, C., and Leimeister, J.M., "Der Weg

Zur Effizienten Bereitstellung Kultursensitiver

Dienstleistungen? Erste Schritte Mittels Systematischer

Modularisierung", Dienstleistungsmodellierung (DLM) 2014, 2014

[8] http://www.dgtelemed.de/de/telemedizin/, accessed

17.03.2011,

[9] Peters, C., "Together They Are Strong - the Quest for Service Modularization Parameters", Proceedings of the 22nd European Conference on Information Systems (ECIS), 2014

[10] Berry, L.L., and Bendapudi, N., "Health Care: A Fertile Field for Service Research", Journal of Service Research, 10(2), 2007, pp. 11. 
[11] Cho, S., Mathiassen, L., and Gallivan, M., "Crossing the Chasm: From Adoption to Diffusion of a Telehealth Innovation": Open It-Based Innovation: Moving Towards Cooperative It Transfer and Knowledge Diffusion, Springer, Boston, 2008, pp. 361-378.

[12] Essén, A., "The Emergence of Technology-Based Service Systems: A Case Study of a Telehealth Project in Sweden", Journal of Service Management, 20(1), 2009, pp. 98-121.

[13] http://www.bccresearch.com/report/HLC014D.html, accessed 17.03.2011, 2011.

[14] http://ec.europa.eu/digital-agenda/en/telemedicine, accessed 14.03.2014,

[15] Kerkhoff, M., Geschäftsmodelle in Der Telemedizin Ein Ordnungsrahmen. Morphologie Telemedizinischer Dienstleistungen Im Rahmen Eines Wert- Und Serviceorientierten Geschäftsmodellansatzes. . Master Thesis, Universität Kassel, 2013.

[16] Alter, S., "Metamodel for Service Design and Service Innovation: Integrating Service Activities, Service Systems, and Value Constellations", in (Editor, 'ed.'^'eds.'): Book Metamodel for Service Design and Service Innovation: Integrating Service Activities, Service Systems, and Value Constellations, Shanghai, China, 2011

[17] Maglio, P.P., Srinivasan, S., Kreulen, J.T., and Spohrer, J., "Service Systems, Service Scientists, Ssme, and Innovation", Communications of the ACM, 49(7), 2006, pp. 81-85.

[18] Rajala, R., Rossi, M., and Tuunainen, V.K., "A Framework for Analyzing Software Business Models", in (Editor, 'ed.'^'eds.'): Book A Framework for Analyzing Software Business Models, Naples, Italy, 2003, pp. 16141627.

[19] Järvelä, P., Loikkanen, J., Tinnilä, M., and Tuunainen, V.K., "Business Models for Electronic Commerce in the Travel Services", Information Technology \& Tourism, 2(3), 1999, pp. 185-196.

[20] Timmers, P., "Business Models for Electronic Markets", Electronic markets, 8(2), 1998, pp. 3-8.

[21] Kerkhoff, M., Kromat, T., and Peters, C., "Geschäftsmodelle in Der Telemedizin - Ein Ordnungsrahmen. Morphologie Telemedizinischer Dienstleistungen Im Rahmen Eines Wert- Und Serviceorientierten Geschäftsmodellansatzes.", in (Editor, 'ed.'^'eds.'): Book Geschäftsmodelle in Der Telemedizin - Ein Ordnungsrahmen. Morphologie Telemedizinischer Dienstleistungen Im Rahmen Eines Wert- Und Serviceorientierten Geschäftsmodellansatzes., Kassel, Germany, 2014

[22] Bieger, T.R., Stephan, "Das Wertbasierte Geschäftsmodell - Ein Aktualisierter Strukturierungsansatz. ", in (Bieger, T.Z.K.-A., Dodo; Krys, Chirstian, 'ed.' Innovative Geschäftsmodelle., Springer Berlin Heidelberg, Berlin, Heidelberg, 2011, pp. 13-70.

[23] Osterwalder, A., and Pigneur, Y., "Clarifying Business Models: Origins, Present, and Future of the Concept", Communications of the association for Information Systems, $16(2005$,

[24] Osterwalder, A., and Pigneur, Y., Business Model Generation: A Handbook for Visionaries, Game Changers, and Challengers, John Wiley \& Sons, 2010.
[25] Wirtz, B.W., and Becker, D.R., "Geschäftsmodelle Im Electronic Business": Handbuch Electronic Business, Springer, 2002, pp. 909-935.

[26] Ansorge, B., Dünnebacke, D., Dornberg, J.H., and Amini, A., "Möglichkeiten Der Etablierung Von Telemedizinischen Lösungen Im Gesundheitsmarkt Am Beispiel Des Medina-Systems", in (Editor, 'ed.'^'eds.'): Book Möglichkeiten Der Etablierung Von Telemedizinischen Lösungen Im Gesundheitsmarkt Am Beispiel Des MedinaSystems, Gabler Verlag, Wiesbaden, 2012

[27] Gersch, M., and Hewing, M., "Aal-Geschäftsmodelle Im Gesundheitswesen - Eine Empirisch Gestützte Typologie Relevanter Grundtypen Ökonomischer Aktivitäten Zur Nutzung Von Ambient Assisted Living in Sich Verändernden Wertschöpfungsketten", in (Editor, 'ed.'^'eds.'): Book AalGeschäftsmodelle Im Gesundheitswesen - Eine Empirisch Gestützte Typologie Relevanter Grundtypen Ökonomischer Aktivitäten Zur Nutzung Von Ambient Assisted Living in Sich Verändernden Wertschöpfungsketten, Gabler Verlag, Wiesbaden, 2012

[28] Schultz, C., Gemünden, H.G., and Salomo, S., "Akzeptanz Der Telemedizin", in (Editor, 'ed.'^'eds.'): Book Akzeptanz Der Telemedizin, Minerva, Darmstadt, 2005 [29] Gemünden, H.G., Hensel, K., and Schultz, C., "Erfolgsfaktoren Telemedizinischer Dienstleistungen. Ergebnisse Der Tu-Berlin Im Auftrag Des Bmbf", in (Editor, 'ed.'^'eds.'): Book Erfolgsfaktoren Telemedizinischer Dienstleistungen. Ergebnisse Der Tu-Berlin Im Auftrag Des Bmbf, 2002

[30] Osl, P.S., Ernst; Österle, Hubert; Fischer, Andy, "Erfolgreiche Telemedizinlösungen Und Kundenakzeptanz Zukünftiger Weiterentwicklungen: Das Geschäftsmodell Des Schweizer Zentrums Für Telemedizin Medgate", in (Editor, 'ed.'^'eds.'): Book Erfolgreiche Telemedizinlösungen Und Kundenakzeptanz Zukünftiger Weiterentwicklungen: Das Geschäftsmodell Des Schweizer Zentrums Für Telemedizin Medgate, VDE Verlag GmbH, Berlin, 2009

[31] Valeri, L., Giesen, D., Jansen, P., and Klokgieters, K., "Business Models for Ehealth. Rand Europe and Capgemini Consulting", in (Editor, 'ed.'^'eds.'): Book Business Models for Ehealth. Rand Europe and Capgemini Consulting, 2010 [32] Simon, H.A., The Sciences of the Artificial, The MIT Press, Third Edition edn, Cambridge, Massachusetts, USA and London, England, 1996.

[33] Osterwalder, A., Pigneur, Y., and Clark, T., Business Model Generation. A Handbook for Visionaries, Game Changers, and Challengers, Wiley, Hoboken, NJ, 2010. [34] Vargo, S., and Lusch, R., "Service-Dominant Logic: Continuing the Evolution", Journal of the Academy of Marketing Science, 36(1), 2008, pp. 1-10.

[35] Vargo, S.L., and Lusch, R.F., "Evolving to a New Dominant Logic for Marketing", The Journal of Marketing, 2004, pp. 1-17.

[36] Bieger, T., and Reinhold, S., "Das Wertbasierte Geschäftsmodell - Ein Aktualisierter Strukturierungsansatz", in (Bieger, T., Zu Knyphausen-Aufseß, D., and Krys, C., 'eds.'): Innovative Geschäftsmodelle, Springer Berlin Heidelberg, 2011, pp. 13-70.

[37] Limburg, A.H.M.V.V.G.-P., J. , "Towards Innovative Business Modeling for Sustainable Ehealth Applications", 2010 Second International Conference on eHealth, 
Telemedicine, and Social Medicine (ETELEMED), 2010, pp.

11-16.

[38] Hevner, A.R., "The Three Cycle View of Design

Science Research", Scandinavian Journal of Information

Systems, 19(2), 2007, pp. 87.

[39] Zolnowski, A., Weiß, C., and Böhmann, T.,

"Representing Service Business Models with the Service

Business Model Canvas - the Case of a Mobile Payment

Service in the Retail Industry", in (Editor, 'ed.'^'eds.'): Book

Representing Service Business Models with the Service

Business Model Canvas - the Case of a Mobile Payment

Service in the Retail Industry, 2014

[40] Lindman, J., Rossi, M., and Tuunainen, V.K., "Open

Data Services: Research Agenda", in (Editor, 'ed.'^'eds.'):

Book Open Data Services: Research Agenda, 2013, pp.

1239-1246.

[41] Latif, A., Saeed, A.U., Hoefler, P., Stocker, A., and

Wagner, C., "The Linked Data Value Chain: A Lightweight
Model for Business Engineers", Proceedings of I-Semantics, 2009, pp. 568-577.

[42] Tammisto, Y., and Lindman, J., "Open Data Business Models", in (Editor, 'ed.'^'eds.'): Book Open Data Business Models, 2011, pp. 762-777.

[43] Peters, C., and Leimeister, J.M., "Tm³ - a Modularization Method for Telemedical Services: Design and Evaluation", in (Editor, 'ed.'^'eds.'): Book $\mathrm{Tm}^{3}$ - a Modularization Method for Telemedical Services: Design and Evaluation, Utrecht, the Netherlands, 2013

[44] Gregor, S., and Jones, D., "The Anatomy of a Design Theory", Journal of the Association for Information Systems, 8(5), 2007, pp. 312-335. 


\section{Appendix}

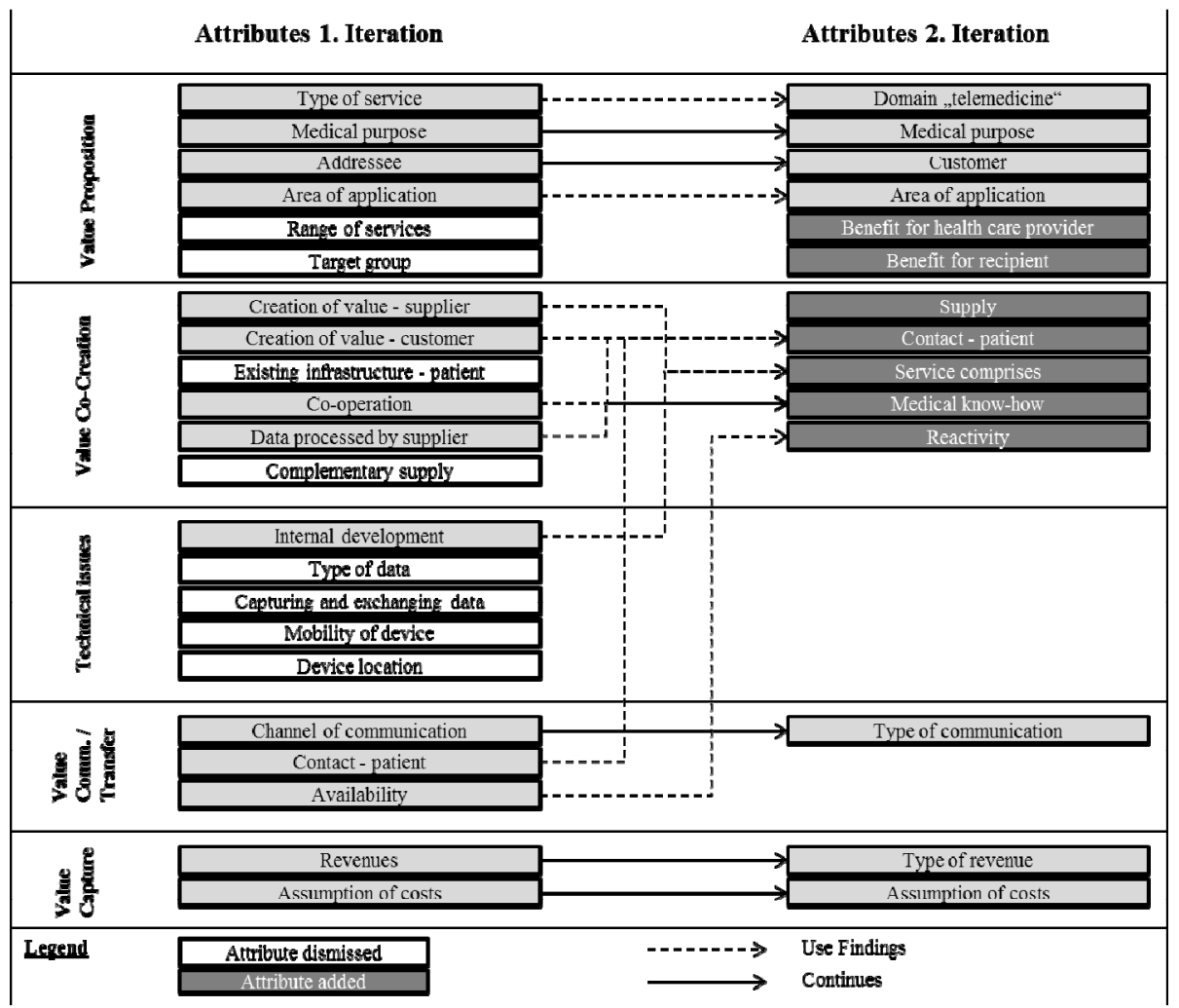

Figure 5. Backing the analysis framework by using value- and service-oriented aspects (source: own illustration)

\begin{tabular}{|c|c|c|}
\hline Dimension & $\begin{array}{l}\text { Characteristic } \\
\text { (attribute) }\end{array}$ & Charateristic value \\
\hline \multirow{6}{*}{ 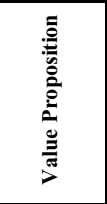 } & Service scope & National \\
\hline & Medical purpose & Prevention \\
\hline & Type of service & Monitoring and recording a patient's blood pressure; data is saved in a patient's electronic health record \\
\hline & Addressee & Focus on patient (consumer); relatives are focused as well (think of parents [customers] who pay for their child's medical treatment) \\
\hline & Target group & Patients suffering from chronical illnesses \\
\hline & Area of application & Chronic illness \\
\hline \multirow{6}{*}{ 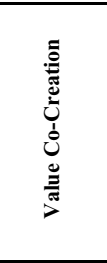 } & $\begin{array}{l}\text { Existing infrastructure - } \\
\text { supplier }\end{array}$ & $\begin{array}{l}\text { Provides hardware (device used to measure blood pressure); processes and saves data; informs patient, if blood pressure reaches a } \\
\text { critical level }\end{array}$ \\
\hline & $\begin{array}{l}\text { Existing infrastructure - } \\
\text { patient }\end{array}$ & Landline, internet access (E-Mail address), mobile telefon \\
\hline & Patient's active participation & Gathering data \\
\hline & Co-operation & Supports health care provider (physician) in diagnosing; physician gets information that could inform about drugs' effectiveness \\
\hline & Data gathered by supplier & Complete (gathering, processing, and internal software) \\
\hline & Complementary supply & $\begin{array}{l}\text { 1) Patient's electronical health record, development of blood pressure; 2) provides information for a healthier life; 3) reminder function } \\
\text { (push effect) }\end{array}$ \\
\hline \multirow{6}{*}{ 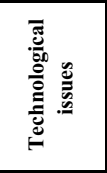 } & Internal development & Unknown \\
\hline & Data & Blood pressure is gathered by the patient her-/ himself \\
\hline & Frequency & Unknown \\
\hline & Gathering and exchaning data & Automated \\
\hline & Mobility of device & Mobile \\
\hline & Device location & At the patient's home \\
\hline \multirow{3}{*}{ 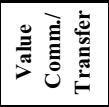 } & Channel of communication & Fully electronic \\
\hline & Contact - patient & $\begin{array}{l}\text { Service (monitoring and recording); no contact, if blood pressure reaches a critical level; patient is informed in written form (E-Mail, } \\
\text { SMS) }\end{array}$ \\
\hline & Availability & 24/7 (personal contact is not necessary) \\
\hline \multirow{2}{*}{ 詞 } & Revenues & Direct; irrespective of transaction (monthly basic charge) \\
\hline & Assumption of costs & Unknown \\
\hline
\end{tabular}

Figure 6. Exemplified TMS - results of the first iteration (source: own illustration) 